\title{
Mapping goliath grouper aggregations in the southwestern Atlantic
}

\author{
Vinicius Jose Giglio ${ }^{1 *}$, Jonas Rodrigues Leite ${ }^{2,3}$, Matheus Oliveira Freitas ${ }^{2,3}$, Mauricio Hostim-Silva ${ }^{3,4}$ \\ ${ }^{1}$ Programa de Pós-Graduação em Ecologia, Universidade Federal do Rio de Janeiro. \\ (Avenida Carlos Chagas Filho, Cidade Universitária, Rio de Janeiro, RJ, CEP: 21941-902) \\ ${ }^{2}$ Instituto de Pesquisas Jardim Botânico do Rio de Janeiro. \\ (Rua Jardim Botânico, Jardim Botânico, Rio de Janeiro, RJ, CEP: 22.460-000) \\ ${ }^{3}$ Instituto Meros do Brasil. \\ (Curitiba, PR, Brazil) \\ ${ }^{4}$ Universidade Federal do Espírito Santo, DCAB/CEUNES. \\ (BR-101, São Mateus, ES, CEP: 29932-540)
}

*Corresponding author: vj.giglio@gmail.com

The Atlantic goliath grouper, Epinephelus itajara (Lichtenstein, 1822), is the largest reef fish in the western Atlantic Ocean, reaching up to 2.5 meters long and $>400 \mathrm{~kg}$ (BULLOCK et al., 1992). The species matures at 5-8 years with a maximum age of 37 years (BULLOCK et al., 1992). Some characteristics of goliath grouper that make them particularly vulnerable to overfishing include their large body size, slow growth, high longevity, late maturity, and the formation of predictable seasonal spawning aggregations (SADOVY; EKLUND, 1999). Consequently, the species has suffered sharp population declines across its entire distribution range (CRAIG et al., 2009; McCLENACHAN, 2009; GIGLIO et al., 2015) and currently is classified as Critically Endangered by the International Union for the Conservation of Nature (CRAIG, 2011). In Brazil, the species have been fully protected by a federal law since 2002, however, illegal fisheries threaten the population's recovery (GIGLIO et al., 2014a).

During the reproductive season, goliath grouper form relatively small (10 to 100 individuals) spawning aggregations (SADOVY; EKLUND, 1999) with individuals migrating distances up to $300 \mathrm{~km}$ to specific spawning areas (PINA-AMARGÓS; GONZÁLEZSANSÓN, 2009). Data on the spatial and temporal distributions of spawning aggregations are mostly available for the northern hemisphere (SADOVY; EKLUND, 1999; MANN et al., 2009; KOENIG et al., 2011; 2016). In Brazil, anecdotal reports of aggregation sites have been described using fishers' knowledge (GERHARDINGER et al., 2009; FERREIRA et al., 2014) and in situ surveys (FÉLIX-HACKRADT; HACKRADT, 2008; BUENO et al., 2016). Identification and management of aggregation sites continues to be a critical component of conservation (SADOVY DE MITCHESON et al., 2012), as spawning aggregations are often exploited at unsustainable levels before fishery managers learn of their existence (ERISMAN et al., 2015).

Here, we describe the occurrence of goliath grouper aggregations along the Brazilian coast, using data compiled from literature, fishermen catches and divers' sightings. Identifying aggregation sites and the timing of aggregation formation is essential to implementing strategies to combat poaching and recover the population of the species in Brazil.

To collect reports of goliath grouper aggregations in literature, we conducted a search through Scopus and Scielo databases using the words "goliath grouper + aggregation + Brazil" and the Portuguese equivalents "mero + agregação + Brasil". During surveys seeking fishers' and divers' knowledge (e.g. GIGLIO et al., $2014 \mathrm{~b} ; 2015$ ) we interviewed approximately 520 fishers and 100 divers in eight states along the Brazilian coast. We asked respondents if they had witnessed goliath grouper aggregations or knew some colleague who had reported an aggregation. We also conducted a search on aggregation videos on Youtube and Vimeo using the keywords: "agregação + mero", "mero" and "mergulho + meros" and contacted the videos' authors to obtain data. Participants were questioned to provide data on location (coordinates), date of sighting or catch, depth, habitat type, number of individuals observed, and images to confirm the aggregations' occurrence. We considered an aggregation to consist of five or more fish sighted or fished at the same site.

A total of 98 reports of goliath grouper aggregations were described at eleven sites, dating between 1993 and 2015 (Figures 1 and 2, Table 1). The overall abundance was $15.6 \pm 3.3(\mathrm{SE})$ individuals per report. Five aggregations were associated with natural reefs (rocky reefs) and six with artificial reefs (three in shipwrecks, 


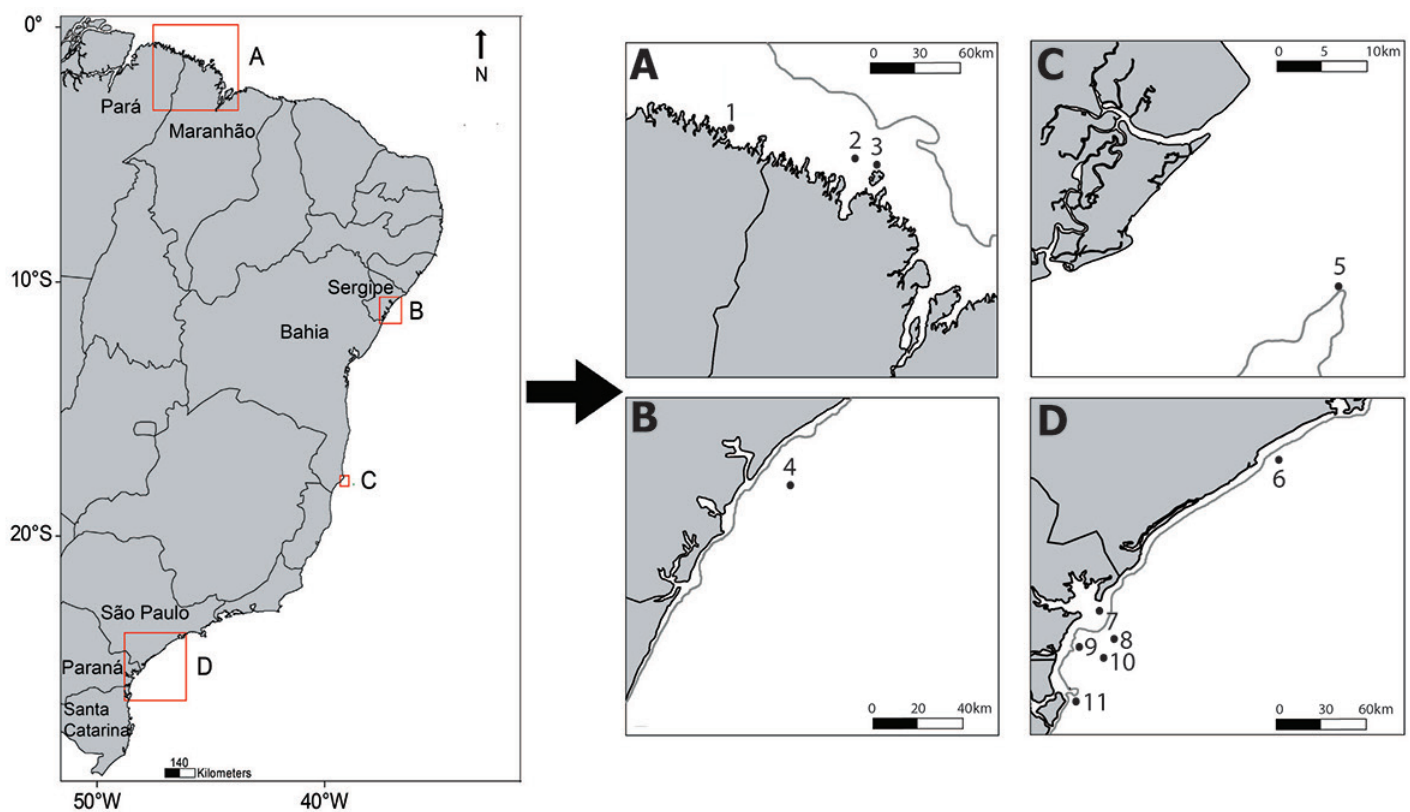

Figure 1. Aggregation sites of goliath grouper along Brazilian coast. Gray lines represent isobaths of a) $30 \mathrm{~m}$. depth and b, c, d) $10 \mathrm{~m}$. depth.

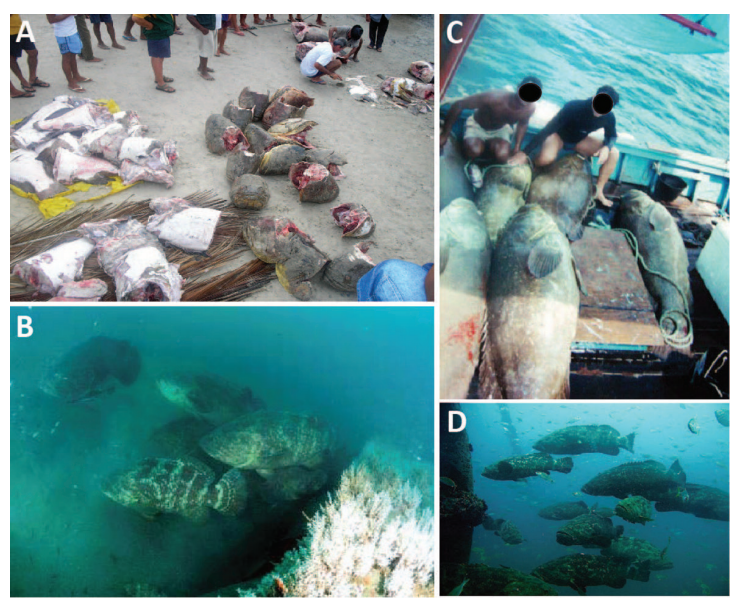

Figure 2. Aggregations of goliath grouper in Brazilian coast: a) Poaching apprehension in Cururupu at February 2009; b) Parque dos Meros at February 2009; c) Abrolhos Bank at March 2000; and d) Monobóia at January 2010. Credits: a) Gerex IBAMA; b) M. Krause; c) Rivelino Nova Viçosa and d) J. Leite.

two in oil-gas structures and one on a concrete reef). Large goliath grouper aggregations ( $>40$ individuals) were recorded in Bragança (state of Pará) and at a mooring buoy located $8 \mathrm{~km}$ offshore, named Monobóia (state of Santa Catarina). Most of aggregation sites $(\mathrm{n}=5)$ were in the southern region. All the aggregations occurred on the continental shelf in shallow waters (6 to $28.8 \mathrm{~m}$ depth) and relatively near the coast $(<42 \mathrm{~km}$; Table 1$)$. Aggregations on artificial and natural reefs occurred within similar depth ranges $(20.3 \pm 2.14 \mathrm{~m}$ and $20 \pm 1.6$ $\mathrm{m}$, respectively). Despite non-significant differences, abundance on natural reefs was higher than on artificial ones $(20 \pm 4.3$ and $13.1 \pm 2.6$ individuals, respectively; Kruskall-Walis test $\left.\mathrm{x}^{2}=2.14 ; p=0.14\right)$. Aggregations occurred during the austral summer (December to March), with peaks in January and February. In southern Brazil, a systematic monitoring verified that abundances on artificial reefs increased in spring and peaked during the austral summer (see BUENO et al., 2016).

Our study revealed the first broad-scale spatial and temporal patterns of goliath grouper aggregations in the southwestern Atlantic. Aggregations were observed in shallow areas $(<30 \mathrm{~m}$ depth) on structurally complex reefs. Goliath grouper are one of the few large groupers that form aggregations on shallow reefs, typically less than $50 \mathrm{~m}$ deep (KOENIG; COLEMAN, 2009). Aggregations are known to occur on high-relief reefs, especially on artificial structures that provide shelter and food (SADOVY; EKLUND, 1999; MANN et al., 2009). In Brazil, artificial reefs generally attract higher abundances of goliath grouper than do the natural ones (SIMON et al., 2011; GIGLIO et al., 2014b). Sites were related to coastal areas relatively close to large estuaries and mangrove areas, which are essential settlement sites for goliath grouper larvae and as nursery habitats for juveniles (SADOVY; EKLUND, 1999; KOENIG et al., 2007).

Female individuals had developed ovaries in austral summer in southern Brazil (BUENO et al., 2016) and 
Table 1. Occurrences of goliath grouper aggregations along the Brazilian Coast. States: $\mathrm{PA}=$ Pará; $\mathrm{MA}=$ Maranhão; $\mathrm{SE}=$ Sergipe; $\mathrm{BA}=$ Bahia; $\mathrm{SP}=$ São Paulo; PR = Paraná, and SC = Santa Catarina. The exact date and geographical coordinates of aggregations are not given in this table so as not to divulge the exact location. Distance from the coast was estimated along a straight line from the nearest point on the coast.

\begin{tabular}{|c|c|c|c|c|c|c|c|c|c|}
\hline Site & Name/state & $\begin{array}{c}\text { Geographical } \\
\text { coordinates }\end{array}$ & $\begin{array}{l}\text { No. of } \\
\text { reports }\end{array}$ & $\begin{array}{l}\text { Date (month/ } \\
\text { year) }\end{array}$ & $\begin{array}{c}\text { No. of } \\
\text { Individuals }\end{array}$ & Depth (m) & $\begin{array}{l}\text { Distance } \\
\text { from the } \\
\text { coast }(\mathrm{km})\end{array}$ & Habitat & Source \\
\hline 1 & Bragança/PA & $\begin{array}{l}39^{\circ} 17^{\prime} \mathrm{S} \\
46^{\circ} 27^{\prime} \mathrm{W}\end{array}$ & 2 & $\begin{array}{c}02 / 2009 \text { and } \\
02 / 2011\end{array}$ & 16 and 44 & $15-22$ & 3 & rocky reef & $\begin{array}{c}\text { ICMBio } \\
\text { (apprehension) }\end{array}$ \\
\hline 2 & $\begin{array}{c}\text { Cururupu/ } \\
\text { MA }\end{array}$ & $\begin{array}{c}1^{\circ} 34^{\prime} \mathrm{S} \\
44^{\circ} 23^{\prime} \mathrm{W}\end{array}$ & 1 & $3 / 2009$ & 17 & 17 & 10 & rocky reef & $\begin{array}{c}\text { IBAMA } \\
\text { (apprehension) }\end{array}$ \\
\hline 3 & $\begin{array}{l}\text { Lençóis de } \\
\text { Cururupu/ } \\
\text { MA }\end{array}$ & $\begin{array}{c}1^{\circ} 25^{\prime} \mathrm{S} \\
44^{\circ} 34^{\prime} \mathrm{W}\end{array}$ & 1 & $2 / 2005$ & 30 & 17 & 1.5 & rocky reef & $\begin{array}{c}\text { ICMBio } \\
\text { and IBAMA } \\
\text { (apprehension) }\end{array}$ \\
\hline 4 & $\begin{array}{l}\text { Plataforma } \\
\text { Sergipe/SE }\end{array}$ & $\begin{array}{c}10^{\circ} 56^{\prime} \mathrm{S} \\
36^{\circ} 50^{\prime} \mathrm{W}\end{array}$ & 1 & $2 / 2008$ & 11 & 20 & 15 & $\begin{array}{l}\text { oil-gas } \\
\text { structure }\end{array}$ & professional diver \\
\hline 5 & $\begin{array}{l}\text { Frias rocky } \\
\text { reefs/BA }\end{array}$ & $\begin{array}{c}17^{\circ} 58^{\prime} \mathrm{S} \\
38^{\circ} 59^{\prime} \mathrm{W}\end{array}$ & 4 & $\begin{array}{c}2 \text { and } 3 / 1993, \\
1 / 1995 \text { and } \\
3 / 2000\end{array}$ & $\begin{array}{c}6,11,8 \text { and } \\
18\end{array}$ & 23 & 35 & rocky reef & fisher \\
\hline 6 & $\begin{array}{l}\text { Queimadi- } \\
\text { nha/SP }\end{array}$ & $\begin{array}{l}24^{\circ} 22^{\prime} \mathrm{S} \\
46^{\circ} 47^{\prime} \mathrm{W}\end{array}$ & 1 & $1 / 2011$ & 6 & 13 & 18 & shipwreck & recreational diver \\
\hline 7 & Castilho/PR & $\begin{array}{l}25^{\circ} 16^{\prime} \mathrm{S} \\
47^{\circ} 57^{\prime} \mathrm{W}\end{array}$ & 2 & $\begin{array}{l}3 / 2010 \\
02 / 2011\end{array}$ & 17 and 8 & 21 & 10 & rocky reef & recreational diver \\
\hline 8 & $\begin{array}{l}\text { Parque dos } \\
\text { Meros/PR }\end{array}$ & $\begin{array}{l}25^{\circ} 49^{\prime} \mathrm{S} \\
48^{\circ} 22^{\prime} \mathrm{W}\end{array}$ & 26 & $\begin{array}{l}\text { spring and } \\
\text { summer } \\
(2006-2015)\end{array}$ & $\begin{array}{c}17,9,7 \\
32 *\end{array}$ & 17 & 32 & $\begin{array}{l}\text { concrete } \\
\text { reef }\end{array}$ & $\begin{array}{c}\text { FELIX- } \\
\text { HACKRADT; } \\
\text { HACKADT } \\
\text { (2008), BUENO } \\
\text { et al. (2016), } \\
\text { recreational diver }\end{array}$ \\
\hline 9 & Dianka/PR & $25^{\circ} 53^{\prime} \mathrm{S}$ & 2 & 2 and $6 / 2009$ & 8 and 7 & 28 & 39 & shipwreck & recreational diver \\
\hline 10 & $\begin{array}{c}\text { Balsa Norte/ } \\
\text { PR* }\end{array}$ & $\begin{array}{l}25^{\circ} 47^{\prime} \mathrm{S} \\
48^{\circ} 06^{\prime} \mathrm{W}\end{array}$ & 25 & $\begin{array}{l}\text { spring and } \\
\text { summer } \\
(2006-2015)\end{array}$ & $30 *$ & 27 & 42 & shipwreck & $\begin{array}{c}\text { BUENO et } \\
\text { al. (2016), } \\
\text { recreational diver }\end{array}$ \\
\hline 11 & $\begin{array}{l}\text { Monobóia/ } \\
\text { SC* }\end{array}$ & $\begin{array}{l}26^{\circ} 13^{\prime} \mathrm{S} \\
48^{\circ} 24^{\prime} \mathrm{W}\end{array}$ & 33 & $\begin{array}{l}\text { spring and } \\
\text { summer } \\
(2006-2015)\end{array}$ & $54 *$ & 23 & 8 & $\begin{array}{l}\text { oil-gas } \\
\text { structure }\end{array}$ & $\begin{array}{l}\text { BUENO et al. } \\
\quad(2016)\end{array}$ \\
\hline
\end{tabular}

* maximum number of individuals sighted, extracted from BUENO et al. (2016). In this reference, the mean abundance per site was not given, thus, to calculate abundance per site we used half of the maximum value. Ex: for the Monoboia, maximum abundance was 54 , so we used 27 as the mean value.

northeastern Brazil (FREITAS et al., 2015) showing that spawning occurs in this season. Our results also ascertained that aggregations occur during the austral summer in shallow waters $(<30 \mathrm{~m}$ depth), similarly to the spawning season for populations in the northern hemisphere (KOENIG et al., 2011). The mapped sites need to be surveyed to verify the occurrence of active spawning aggregations. Sadly, goliath grouper aggregations have been heavily poached, mainly in Northern Brazil (GIGLIO et al., 2014a). A better surveillance of known sites during the spawning season (the austral summer) is urgently needed to curb poaching and aid in the recovery and conservation of this critically endangered species.

\section{ACKNOWLEDGMENTS}

We wish to thank E. Marcovaldi (Atlântico Sul Imagens), I. Cerutti, A. Calomeno, Rivelino, C. Martins Buiú (Abrolhos Sub) and R. Baracho (Scubasul Dive
Center) for images and reports; Petrobras and Fundação Grupo o Boticário de Proteção à Natureza for their financial support. We would also thank Chris Koenig and Ryan Mckenzie for their comments.

\section{REFERENCES}

BUENO, L. S.; BERTONCINI, A. A.; KOENING, C. C.; COLEMAN, F. C.; FREITAS, M. O.; LEITE, J. R.; SOUZA, T. F.; HOSTIM-SILVA, M. Evidence for spawning aggregations of the endangered Atlantic goliath grouper Epinephelus itajara in southern Brazil. J. Fish Biol., v. 89, n. 1, p. 876-889, 2016.

BULLOCK, L. H.; MURPHY, M. D.; GODCHARLES, M. F.; MITCHELL, M. E. Age, growth, and reproduction of jewfish Epinephelus itajara in the eastern Gulf of Mexico. Fish. Bull., v. 90, n. 2, p. 243-249, 1992.

CRAIG, M. T.; GRAHAM, R. T.; TORRES, R. A.; HYDE, J. R.; FREITAS, M. O.; FERREIRA, B. P.; HOSTIM-SILVA, M.; GERHARDINGER, L. C., BERTONCINI, A. A.; ROBERTSON, D. R. How many species of goliath grouper are there? Cryptic genetic divergence in a threatened marine fish and the resurrection of a geopolitical species. Endang. Species Res., v. 7, n. 3, p. 167-174, 2009. 
CRAIG, M.T., 2011. Epinephelus itajara. In: IUCN Red List of Threatened Species v. 2012.1, Available at http://www. iucnredlist.org/details/195409/0

ERISMAN, B.; HEYMAN, W.; KOBARA, S.; EZER, T.; PITTMAN, S. ABURTO-OROPEZA, O.; NEMETH, R. S. Fish spawning aggregations: where well-placed management actions can yield big benefits for fisheries and conservation. Fish Fish. (Oxf), 2015. http://sites.utexas. edu/fisheries/files/2015/08/Erisman et al-2015-Fish and Fisheries.pdf

FÉLIX-HACKRADT, F. C.; HACKRADT, C. W. Populational study and monitoring of the goliath grouper, Epinephelus itajara (Lichtenstein, 1822), in the coast of Paraná, Brazil. Nat. Conserv., v. 6, p. 31-46, 2008.

FERREIRA, H. M.; REUSS-STRENZEL, G. M.; ALVES, J. A.; SCHIAVETTI, A. Local ecological knowledge of the artisanal fishers on Epinephelus itajara (Lichtesntein, 1822) (Teleostei: epinephelidae) in Ilheus coast-Bahia State, Brazil. J. Ethnobiol. Ethnomed., v. 10, n. 51, 15 p., 2014.

FREITAS, M. O.; ABILHOA, V.; GIGLIO, V. J.; HOSTIMSILVA, M.; MOURA, R. L.; FRANCINI-FILHO, R. B.; MINTE-VERA, C. V. Diet and reproduction of the goliath grouper, Epinephelus itajara (actinopterygii: perciformes: serranidae), in eastern Brazil. Acta Ichthyol. Piscat., v. 45, n. 1, p. 1-11, 2015 .

GERHARDINGER, L. C.; HOSTIM-SILVA, M.; MEDEIROS, R. P.; MATAREZI, J.; BERTONCINI, A. A.; FREITAS, M. O.; FERREIRA, B. P. Fishers' resource mapping and goliath grouper Epinephelus itajara (Serranidae) conservation in Brazil. Neotrop. Ichthyol., v. 7, n. 1, p. 93-102, 2009.

GIGLIO, V. J.; BERTONCINI, A. A.; FERREIRA, B. P.; HOSTIM-SILVA, M.; FREITAS, M. O. Landings of goliath grouper, Epinephelus itajara, in Brazil: despite prohibited over ten years, fishing continues. Nat. Conserv., v. 12, n. 2, p. 118-123, 2014a.

GIGLIO, V. J.; ADELIR-ALVES, J.; GERHARDINGER, L. C.; GRECCO, F. C.; DAROS, F. A.; BERTONCINI, A. A. Habitat use and abundance of goliath grouper, Epinephelus itajara, in Brazil: a participative survey. Neotrop. Ichthyol., v. 12 , n. 4 , p. $803-810,2014$ b.

GIGLIO, V. J.; LUIZ, O. J.; GERHARDINGER, L. C. Depletion of marine megafauna and shifting baselines among artisanal fishers in eastern Brazil. Anim. Conserv., v. 18, n. 4, p. 348-358, 2015.
KOENIG, C. C.; BUENO, L. S.; COLEMAN, F. C.; CUSICK, J.A.; ELLIS, R.D.; KINGON, K.K.; LOCASCIO, J.V.; MALINOWSKI, C.; MURIE, D.J.; STALLINGS, C.D. Diel, lunar, and seasonal spawning patterns of the Atlantic goliath grouper, Epinephelus itajara, off Florida, United States. Bull. Mar. Sci., v.92, http://dx.doi.org/10.5343/ bms.2016.1013, 2016.

KOENIG, C. C.; COLEMAN, F. C. Population density, demographics, and predation effects of adult goliath grouper. Project NA05NMF4540045 (FSU Project No. 016604). Tallahassee: Florida State University, 2009.

KOENIG, C. C.; COLEMAN, F. C.; EKLUND, A. M., SCHULL, J.; UELAND, J. Mangroves as essential nursery habitat for goliath grouper (Epinephelus itajara). Bull. Mar. Sci., v. 80, n. 3, p. 567-585, 2007.

KOENIG, C. C.; COLEMAN, F. C.; KINGON, K. Pattern of Recovery of the Goliath Grouper Epinephelus Itajara Population in the Southeastern US. Bull. Mar. Sci., v. 87, n. 4, p. 891-911, 2011.

MANN, D. A.; LOCASCIO, J. V.; COLEMAN, F. C.; KOENING, C. C. Goliath grouper Epinephelus itajara sound production and movement patterns on aggregation sites. Endang. Species Res., v. 7, p. 229-236, 2009.

MCCLENACHAN, L. Historical declines of goliath grouper populations in South Florida, USA. Endang. Species Res., v. 7, p. 175-181, 2009.

PINA-AMARGÓS, F.; GONZÁLEZ-SANSÓN, G. Movement patterns of goliath grouper Epinephelus itajara around southeast Cuba: implications for conservation. Endang. Species Res., v. 7, p. 243-247, 2009.

SADOVY, Y.; EKLUND, A. M. Synopsis of biological data on the Nassau grouper, Epinephelus striatus (Bloch, 1792), and the jewfish, E. itajara (Lichenstein, 1822). Seattle: NOAA/ National Marine Fisheries Service, (NOAA Technical Report NMFS, 146), 1999.

SADOVY DE MITCHESON, Y.; COLIN, P. L. Reef Fish Spawning Aggregations: Biology, Research and Management. Amsterdam: Springer, 2012, 584 p.

SIMON, T.; PINHEIRO, H. T.; JOYEUX, J. C. Target fishes on artificial reefs: Evidences of impacts over nearby natural environments. Sci. Total Environ., v. 409, n. 21, p. $4759-4584,2011$.

Braz. j. oceanogr. vol.64 no.4 São Paulo Oct./Dec. 2016.

Mapping goliath grouper aggregations in the southwestern Atlantic

Vinicius Jose Giglio, Jonas Rodrigues Leite, Matheus Oliveira Freitas, Mauricio Hostim-Silva

Onde se Lê no Rodapé:

BRAZILIAN JOURNAL OF OCEANOGRAPHY, 64(4):417-420;2016

Leia-se:

BRAZILIAN JOURNAL OF OCEANOGRAPHY, 64(4): 423-426;2016 